\title{
Pembelajaran Karakter Melalui Media Dongeng pada PAUD Formal Binaan I Dan Binaan III Ciracas Jakarta Timur
}

\author{
Lanny Polina $^{1^{*}}$ dan Puri Pramudiani ${ }^{1}$ \\ ${ }^{1}$ Universitas Muhammadiyah Prof. Dr. Hamka, Jl. Tanah Merdeka, Kp. Rambutan, Ciracas, Jakarta Timur \\ Email koresponden: lanny polina@ymail.com
}

\begin{abstract}
Abstrak
Pendidikan di Indonesia akhir-akhir ini juga dinilai sarat dengan muatan-muatan pengetahuan dan tuntutan arus global yang mana mengesampingkan nilai-nilai moral budaya dan budi pekerti dalam membentuk karakter siswa, sehingga menghasilkan siswa yang pintar tetapi tidak bermoral. Dimana, pendidikan karakter sendiri harus meliputi dan berlangsung pada setiap jenjang pendidikan. Pelatihan dalam kegiatan pengabdian ini bertujuan untuk: (1) Meningkatkan pemahaman guru-guru PAUD dalam memahami pendidikan karakter melalui media dongeng, dan (2) Meningkatkan kemampuan guru dalam membuat langkah-langkah mendongeng yang baik. Metode yang digunakan dalam kegiatan pengabdian adalah metode ceramah dan diskusi. Metode ceramah untuk menyampaikan membangun karakter anak dengan dongeng dan penggunaan media dalam pembelajaran berbasis karakter, sedangkan metode diskusi untuk memberikan kesempatan guru dalam membuat langkah-langkah mendongeng yang baik. Dalam pelaksanaan pelatihan ini, guru akan bertindak sebagai peserta aktif partisipatoris. Selain mendengarkan uraian dari narasumber, guru akan diberikan kesempatan untuk belajar langsung dan mempraktekkan membuat langkah-langkah mendongeng. Evaluasi pelaksanaan program pengabdian kepada masyarakat menggunakan angket. Berdasarkan hasil angket yang terkumpul, diperoleh keterangan bahwa 91,5\% peserta kegiatan menyatakan kegiatan penyuluhan ini tergolong sangat baik. Secara keseluruhan kegiatan penyuluhan pendidikan karakter melalui media dongeng ini dapat dikatakan berhasil.
\end{abstract}

Kata kunci: Pendidikan Karakter, Media Dongeng, Guru, PAUD

\begin{abstract}
Education in Indonesia lately is also considered with contents of knowledge and demands of global currents which override the moral values of culture and character in shaping the character of students, resulting in students who are smart but not moral. Where, character education itself should include and take place at every level of education. Training in this devotional activity aims to: (1) Improve understanding of PAUD teachers in understanding character education through fairy tales, and (2) Improving teachers' ability in making good storytelling steps. The methods used in devotional activities are lecture and discussion methods. The lecture method is to convey the character building of children with fairy tales and the use of media in character-based learning, while the method of discussion to give teachers a chance in making good storytelling steps. In the implementation of this training, the teacher will act as a participant actively participant. In addition to listen to descriptions from resource persons, teachers will be given the opportunity to learn firsthand and practice making storytelling steps. Evaluating the implementation of community service programs using questionnaires. Based on the results of questionnaires collected, obtained information that $91.5 \%$ of participants stated that this extension activity is very good. Overall education activities character education through this fairy tale can be said to be successful.
\end{abstract}

Keywords: Training, Character Education, Media Tale, PAUD Teachers

Format Sitasi: Paulina L. \& Pramudiani P. (2018). Pembelajaran Karakter melalui Media Dongeng pada PAUD Formal Binaan I Dan Binaan III Ciracas Jakarta Timur. Jurnal SOLMA, 01(1), 215-224. Doi: http://dx.doi.org/10.29405/solma.v7i2.1665.

Diterima: 8 Agustus 2018 | Revisi: 23 Oktober 2018 | Dipublikasikan: 30 Oktober 2018 


\section{PENDAHULUAN}

Masyarakat Indonesia mengalami perubahan yang sangat cepat terutama dalam bidang teknologi, struktur ekonomi, struktur keluarga, perkembangan moral dan budaya. Era kemajuan teknologi informasi dan telekomunikasi saat ini menjadi salah satu faktor yang berpengaruh sangat besar dalam pembangunan karakter bangsa terutama media massa, khususnya media elektronik dengan pelaku utama televisi (Tim Pakar Yayasan Jati Diri Bangsa, 2011). Salah satunya adalah pengaruhnya dalam hal pola pikir dan tindakan masyarakat baik di kota maupun di desa. Keramahan, tenggang rasa, kesopanan, rendah hati, suka menolong, solidaritas sosial yang mana merupakan jati diri bangsapun dewasa ini seolah-olah hilang.

Terpuruknya bangsa Indonesia sekarang ini tidak hanya disebabkan oleh krisis ekonomi dan arus globalisasi saja melainkan juga makin terpuruknya dunia pendidikan. Pendidikan di Indonesia akhir-akhir ini juga dinilai sarat dengan muatan-muatan pengetahuan dan tuntutan arus global yang mana mengesampingkan nilai-nilai moral budaya dan budi pekerti dalam membentuk karakter siswa, sehingga menghasilkan siswa yang pintar tetapi tidak bermoral. Fenomena ini sesungguhnya menjadi tantangan bagi bangsa Indonesia, dimana pendidikan itu seharusnya mampu menjadi suatu wadah untuk mengembangkan dan membentuk watak serta peradaban bangsa. Hal ini sebagaimana yang terdapat dalam Undang-Undang Republik Indonesia nomor 20 tahun 2003 Pasal 3 yaitu:

"Pendidikan nasional berfungsi untuk mengembangkan dan membentuk watak serta peradaban bangsa yang bermartabat dalam rangka mencerdaskan kehidupan bangsa, dengan tujuan dapat berkembangnya potensi siswa agar menjadi manusia yang beriman dan bertakwa kepada Tuhan Yang Maha Esa, berakhlak mulia, sehat, berilmu, cakap, kreatif, mandiri, dan menjadi warga negara yang demokratis serta bertanggung jawab."

Tujuan pendidikan nasional yang tercantum dalam Undang-Undang tersebut menyebutkan bahwa pemerintah mengusahakan dan menyelenggarakan suatu sistem pendidikan nasional untuk meningkatkan keimanan serta akhlak mulia dalam rangka pula untuk mencerdaskan kehidupan bangsa. Untuk mencapai tujuan dari pendidikan nasional serta untuk mengatasi permasalahan moralitas bangsa, diperlukan suatu sistem pendidikan yang menyentuh seluruh jalur dan jenjang yaitu pendidikan karakter. Pendidikan karakter dipilih sebagai suatu upaya perwujudan pembentukan karakter siswa ataupun generasi bangsa yang berakhlak mulia. Hal tersebut sesuai dengan yang sebagaimana diungkapkan oleh Frye (Darmiyati, 2011), bahwa pendidikan karakter merupakan usaha yang disengaja 
untuk membantu seseorang memahami, menjaga, dan berperilaku yang sesuai dengan nilai-nilai karakter mulia.

Dalam proses pendidikan karakter sendiri diperlukan kelanjutan dan tidak berakhir (never ending process), sebagaimana bagian yang terpadu untuk menyiapkan masa depan, berakar pada filosofi dan nilai kultural religius bangsa Indonesia (Mulyasa, 2011). Dimana, pendidikan karakter sebagai upaya untuk membantu perkembangan jiwa anak-anak baik lahir maupun batin, dari sifat alaminya menuju kearah peradaban yang manusiawi dan lebih baik. Melalui penekanan dan pemberdayaan penerapan pendidikan karakter diberbagai lembaga pendidikan, baik informal, formal maupun nonformal diharapkan mampu pula menjawab berbagai tantangan serta permasalahan kompleks yang dialami bangsa Indonesia. Dimana, pendidikan karakter sendiri harus meliputi dan berlangsung pada setiap jenjang pendidikan. Pendidikan karakter dilakukan melalui pendidikan formal, informal dan non-formal. Pada jalur pendidikan formal maka pendidikan yang paling dasar adalah PAUD sehingga pendidikan karakter secara formal juga dimulai di sini (Sari dan Fitroh, 2015).

Pendidikan anak usia dini adalah pendidikan yang utama dan pertama bagi anak dimana anak-anak pada masa itu mendapatkan segala sesuatu yang dapat membantu dalam proses perkembangan maupun pertumbuhannya dari luar dirinya berupa stimulasi ataupun rangsangan-rangsangan dan nilai-nilai yang berguna bagi kehidupannya. Pada usia ini pula merupakan saat yang tepat untuk memberikan stimulasi ataupun rangsangan yang baik untuk anak. Seperti yang tercantum dalam Undang-Undang Sisdiknas nomor 20 tahun 2003 pasal 1 ayat 14 yaitu:

"Pendidikan anak usia dini adalah upaya pembinaan yang ditujukan kepada anak sejak lahir sampai dengan usia enam tahun yang dilakukan melalui pemberian rangsangan pendidikan untuk membantu pertumbuhan perkembangan jasmani dan rohani agar anak memiliki kesiapan dalam memasuki pendidikan lebih lanjut."

Walaupun pada dasarnya setiap manusia itu memiliki potensi untuk berkarakter sesuai dengan keadaan pada saat ia dilahirkan, tetapi dalam perjalanan kehidupannya setiap manusia memerlukan proses yang panjang dalam pembentukan karakter dan dimulai sejak usia dini. Hal ini dikarenakan, pada usia anak-anak (the golden age) adalah waktu yang tepat untuk menanamkan nilai-nilai karakter yang nantinya diharapkan akan membentuk kepribadiannya. Berdasarkan hasil penelitian yang dikemukakan Gadner (Mulyasa, 2012) 
bahwa anak usia dini mengalami perkembangan yang sangat pesat mencapai $80 \%, 50 \%$ dari dilahirkan sampai usia 4 tahun, 30\% lagi bertambah sampai anak berumur 8 tahun. Dan nantinya selebihnya berkembang sampai 18 tahun.

Penelitian ini menunjukkan bahwa pada rentang usia dini merupakan masa yang tepat untuk dilakukan pendidikan karakter dikarenakan kemampuan otak dalam hal yang menyerap nilai-nilai berkembang dengan baik dan menjadikan nilai-nilai tersebut dapat menjadi kebiasaan ketika dewasa. Pendidikan merupakan masa persiapan untuk sekolah pada tingkatan selanjutnya maka penanaman karakter baik pada usia prasekolah merupakan hal yang sangat penting dilakukan. Kelompok bermain (KB) adalah salah satu bentuk layanan pendidikan bagi anak usai 3 sampai dengan usia 5 yang berfungsi untuk membantu meletakkan dasar kearah perkembangan sikap, pengetahuan, dan keterampilan yang diperlukan bagi anak untuk menyesuaikan diri dengan lingkungannya dan untuk pertumbuhan dan perkembangan selanjutnya, termasuk untuk siap memasuki pendidikan dasar.

Pada kenyataannya pembelajaran karakter anak yang terjadi di lembaga kelompok bermain belum tercapai sesuai dengan apa yang diharapkan, diantaranya mengenalkan tata cara sholat, menuruti nasehat orangtua, dan tutur kata yang sopan santun. Anak sulit untuk diberikan kegiatan pengenalan untuk melakukan sholat, anak yang kurang dapat mendengarkan perkataan orangtuanya dan tutur kata yang kurang sopan pada guru dan orangtua. Hal ini menunjukkan bahwa karakter anak usia dini belum menunjukkan sikap yang positif sebagaimana yang kita harapkan dalam pendidikan karakter bangsa dan sesuai latarbelakang pentingnya pendidikan karakter.

Pembentukan karakter anak memang tidak dapat dilakukan dalam waktu yang singkat karena membutuhkan proses panjang dalam waktu yang lama. Hal tersebut juga dilakukan secara terus-menerus dengan menggunakan metode yang tepat dan efektif. Salah satu cara menyenangkan yang dapat digunakan untuk membentuk karakter anak adalah melalui dongeng. Menurut Pusat Bahasa (2003), dongeng adalah cerita yang tidak benar benar terjadi atau cerita bohong. Salah satu unsur intrinsik yang ada dalam dongeng adalah memiliki amanat atau pesan moral. Oleh karena itu, dongeng bisa dijadikan sebagai media untuk membentuk karakter anak karena memiliki nilai budi pekerti yang bisa dipelajari oleh anak (Habsari, 2017). 
Menurut Sari dan Fitroh (2015), mendongeng atau aktivitas bercerita merupakan praktik budaya yang alamiah dan sangat baik diberikan sejak anak-anak usia dini. Mendongeng atau bercerita tentang "sesuatu", bisa dilakukan dengan banyak cara agar dongeng lebih menarik dan hidup, misalnya dengan animasi suara melalui aplikasi teknologi informatika atau bantuan alat peraga tradisional. Media boneka tangan merupakan media dalam pembelajaran mendongeng yang sesuai dengan karakteristik anak-anak usia dini yang berada pada tahap pengenalan. Pembelajaran bercerita kadang kurang menarik perhatian anak-anak, akibatnya anak-anak yang malu dan tidak mau bercerita ke depan kelas. Oleh karena itu perlu media boneka sebagai alat bantu untuk menyampaikan materi pembelajaran. Dengan mendongeng dan dibantu media boneka tangan maka anak-anak akan lebih tertarik untuk belajar, kerena dengan cerita anak-anak akan bisa menambah kosa kata bahasa dan kecerdasan linguistiknya terbentuk (Fitriyah, 2018).

Di zaman modern ini, aktivitas mendongeng sudah jarang dilakukan orangtua terhadap anak-anak mereka. Hampir sepertiga orangtua yang menjadi responden mengaku terlalu lelah untuk bercerita, terlebih ketika mereka terlambat pulang kantor dan harus melakukan pekerjaan rumah lainnya. Dari survei Disney tersebut juga terungkap, di era digital seperti sekarang ini, dua pertiga dari orangtua dan kakek-nenek merasa bahwa teknologi modern sudah menghilangkan tradisi mendongeng (Kartikawati, 2012). Jika kejadian ini terus berlanjut, maka anak-anak akan jauh dari akhlak, moral, dan etika baik. Berdasarkan latar belakang di atas, artikel ini membahas masalah tentang (1) dongeng, (2) karakter, (3) nilai-nilai dalam dongeng, dan (4) strategi pembentukan karakter melalui dongeng. Masalah tersebut diungkapkan dengan tujuan memberikan wawasan kepada pendidik akan pentingnya nilai-nilai budi pekerti dalam dongeng sebagai sarana pembentukan karakter anak dan pelestarian budaya Indonesia.

Pembelajaran karakter dalam pembelajaran anak usia dini pada dasarnya dilakukan melalui pembiasaan dan pemodelan yang diberikan orang tua, guru dan orang-orang di sekitar anak. Selain itu, metode pembelajaran juga dapat membantu dalam karakter anak usia dini. Pendidikan anak usia dini (PAUD) jenjang formal di DKI Jakarta sangat banyak dan ini sangat penting dalam penanaman karakter apalagi pusat metropolitan di Jakarta dengan arus globalisasi yang dapat mempengaruhi penanaman karakter siswa, namun 
dalam hal ini tim pelaksana mengambil daerah khusus yang akan dilaksanakan pengabdian masyarakat yakni daerah Ciracas yang memiliki 7 Binaan yang terdiri dari kurang lebih 290 guru. Tim pelaksana pengabdian masyarakat berencana melaksanakan dengan PKM dengan Binaan I dan Binaan III.

Sehubungan dengan teori yang sudah dipaparkan dan mencermati penemuan permasalahan berdasarkan hasil wawancara pada guru-guru PAUD Ciracas diperoleh hasil bahwa mereka memiliki kesulitan dalam hal proses pembelajaran, mendongeng kurang menarik bagi anak, dongeng yang ditampilkan kurang bermakna bagi anak, sehingga minat anak terhadap kegiatan mendongeng masih terlihat rendah. Banyaknya faktor yang ditemui dalam pembelajaran karakter dan adanya keterbatasan pengetahuan. Dengan demikian hal inilah yang menjadi landasan untuk mengadakan pengabdian kepada masyarakat PAUD Ciracas Jakarta Timur Binaan I dan Binaan III.

\section{MASALAH}

Berdasarkan analisis situasi yang dipaparkan terdapat beberapa permasalahan, antara lain:

1. Masih tingginya ekspektasi guru terhadap media berbasis teknologi, bahkan guru menganggap media adalah jurus ampuh dalam memberikan proses pembelajaran yang baik tanpa melihat kreativitas yang lainnya.

2. Minimnya pengetahuan guru mengenai pentingnya penanaman karakter melalui mendongeng karena masih banyak terfokus pada hasil akhir, bukan pada sebuah proses pembelajaran guru melalui kegiatan belajar mendongeng.

3. Sedikitnya pengetahuan guru tentang berbagai dongeng atau cerita rakyat dikarenakan kurangnya membaca.

4. Kurangnya kemampuan guru untuk mendongeng, baik, sikap, intonasi, mimik, maupun ekspresi lainnya yang mencerminkan tokoh-tokoh dalam dongeng.

\section{METODE PELAKSANAAN}

Adapun langkah-langkah kegiatan pengabdian kepada masyarakat yang akan dilaksanakan, terdiri dari 2 tahapan kegiatan yaitu (1) Pendalaman Materi, (2) Pelatihan Pembuatan Langkah-Langkah Mendongeng dan (3) Pembagian Angket. 
1. Pendalaman Materi

Pada kegiatan pendalaman materi disampaikan oleh narasumber yaitu tim pelaksana pengabdian masyarakat. Saat paparan materi dilakukan tanya jawab secara langsung ketika peserta mengalami kesulitan maka peserta secara langsung bertanya kepada narasumber. Pemaparan materi disampaikan 2 topik utama, yaitu (a) Membangun karakter anak dengan dongeng, dan (b) Penggunaan media dalam pembelajaran berbasis karakter. Narasumber dalam PKM ini adalah ibu Lanny Polina R., M.Pd dan ibu Puri Pramudiani, S.Pd., M.Sc. Dalam pelaksanaan pemaparan materi, guru diminta maju untuk membacakan cerita malin kundang dengan tiga versi yaitu: (1) Tanpa Iringan Musik; (2) Dengan iringan musik sedih; (3) Dengan iringan musik lebih kencang. Luaran yang diharapkan pada guru-guru Paud Formal Binaan I dan Binaan III Ciracas Jakarta Timur mampu untuk memiliki panduan langkah-langkah mendongeng yang baik dalam menumbuhkan kreativitas mengajar.

2. Pelatihan Pembuatan Langkah-Langkah Mendongeng

Pada kegiatan ini sebelum membahas tentang langkah-langkah mendongeng yang baik, terdapat penampilan dari mahasiswa PGSD semester VI dalam menampilan dongen dengan media boneka tangan. Selanjutnya, setiap guru dibentuk kelompok sebanyak 5 sampai 6 dan diberikan kertas untuk memulai membuat draft langkahlangkah mendongeng dan membuat cerita dongeng secara singkat kemudian mengkonsultasikan judul tersebut kepada narasumber. Perwakilan maisng-masing kelompok akan diberikan evaluasi oleh narasumber dan diberikan kesempatan untuk mempresentasikan draft langkah-langkah mendongeng yang baik dan mendongeng di depan kelas. Kemudian dilanjutkan menyimpulkan langkah-langkah mendongeng yang benar. Pada kegiatan ini peserta terlibat aktif untuk mengkonsultasikan langkahlangkah mendongeng yang telah dibuat.

3. Pembagian Angket

Angket dibagikan kepada bapak dan ibu guru peserta PKM. Dalam pembagian angket ini difungsikan untuk mengetahui tingkat kepuasan peserta penyuluhan. Berikut sepuluh poin pernyataan yang terdapat di dalam angket yang dibagikan: (1) Materi yang disampaikan dalam Program Kemitraan Masyarakat (PKM); (2) Kejelasan materi; (3) Keterkaitan antara materi dengan aplikasi yang dapat diserap oleh peserta; (4) Keterkaitan materi dengan kebutuhan peserta ; (5) Teknik penyajian; (6) Respon peserta terhadap 
materi yang disampaikan; (7) Waktu yang dipergunakan dalam pemberian materi; (8) Minat peserta terhadap kegiatan PKM; (9) Kejelasan dalam diskusi dan praktek pembuatan proposal PTK; dan (10) Kepuasan kegiatan.

Dalam pelaksanaan pelatihan ini, guru akan bertindak sebagai peserta aktif partisipatoris. Selain mendengarkan uraian dari narasumber, guru akan diberikan kesempatan untuk belajar langsung dan mempraktekkan membuat langkah-langkah mendongeng. Proses pelaksanaan penyusunan pembuatan langkah-langkah mendongeng dapat digambarkan sebagai berikut.

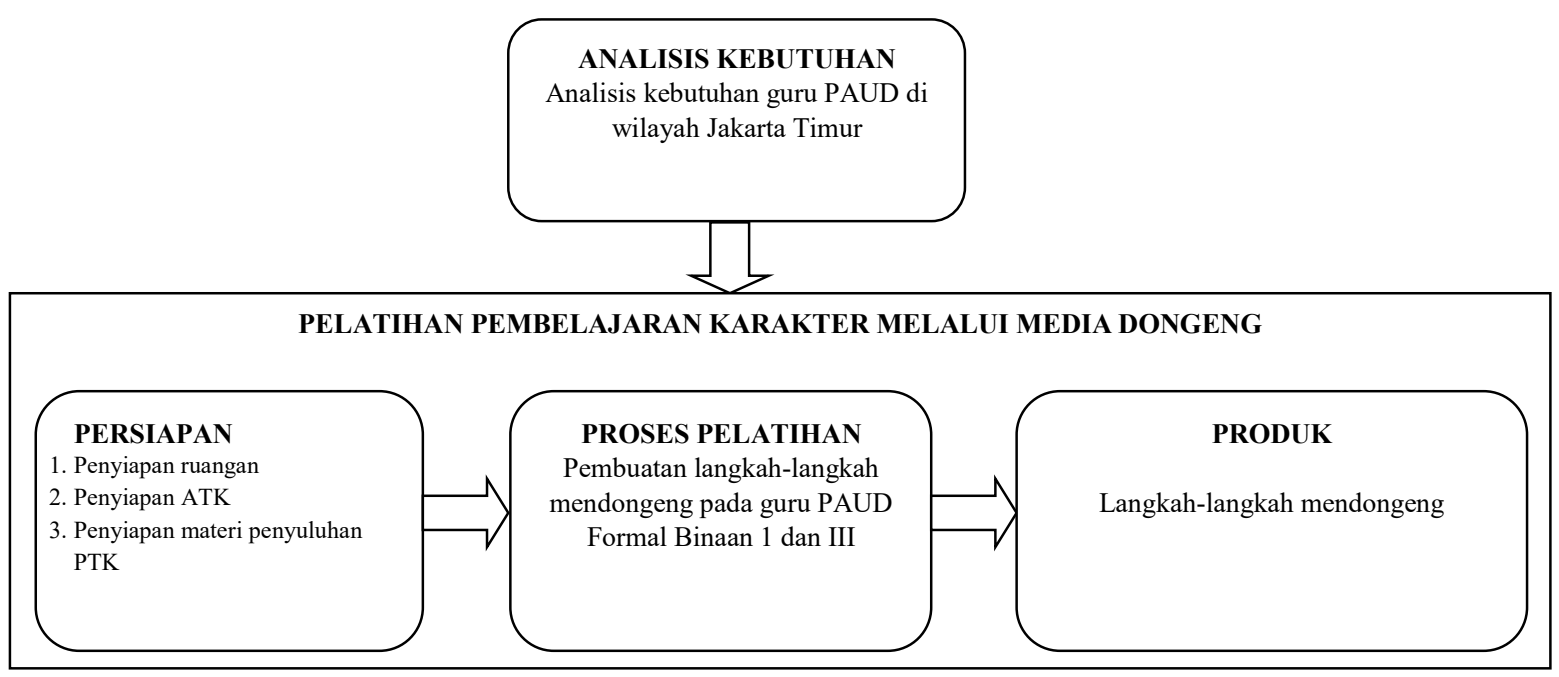

Gambar 1. Pelatihan Pembelajaran Karakter Melalui Media Dongeng

\section{PEMBAHASAN}

Hasil yang dicapai dalam pelaksanaan program pengabdian kepada masyarakat berupa "Pelatihan Pembelajaran Karakter Melalui Media Dongeng Pada Paud Formal Binaan I dan Binaan III Ciracas Jakarta Timur” melalui angket yang terkumpul dari 42 responden, diperoleh keterangan bahwa 91,5\% peserta kegiatan menyatakan kegiatan workshop ini tergolong sangat baik, hal tersebut dapat dilihat pada tabel di bawah ini.

Tabel 1. Kriteria Penilaian Item Dalam Angket

\begin{tabular}{ccc}
\hline Kriteria & Skala Penilaian & Kualifikasi \\
\hline $3.5 \leq$ skor $\leq 40$ & Sangat Baik & Tuntas \\
$2.5 \leq$ skor $<3.5$ & Baik & Tuntas \\
$1.5 \leq$ skor $<2.5$ & Cukup & Tidak Tuntas \\
$1 \leq$ skor $<1.5$ & Kurang & Tidak Tuntas \\
\hline
\end{tabular}


Berdasarkan hasil pada Tabel 1. berikut perolehan nilai setiap item pernyataan dalam angket: (1) Materi yang disampaikan dalam Program Kemitraan Masyarakat (PKM) memperoleh rata-rata 3.48 dengan kategori sangat baik; (2) Kejelasan materi memperoleh rata-rata 3.5 dengan kategori sangat baik; (3) Keterkaitan antara materi dengan aplikasi yang dapat diserap oleh peserta memperoleh rata-rata 3.52 dengan kategori sangat baik; (4) Keterkaitan materi dengan kebutuhan peserta memperoleh rata-rata 3.57 dengan kategori sangat baik; (5) Teknik penyajian memperoleh rata-rata 3.45 dengan kategori sangat baik; (6) Respon peserta terhadap materi yang disampaikan memperoleh rata-rata 3.43 dengan kategori sangat baik; (7) Waktu yang dipergunakan dalam pemberian materi memperoleh rata-rata 3.48 dengan kategori sangat baik; (8) Minat peserta terhadap kegiatan PKM memperoleh rata-rata 3.74 dengan kategori sangat baik; (9) Kejelasan dalam diskusi dan praktek pembuatan langkah-langkah mendongeng yang baik memperoleh rata-rata 3.95 dengan kategori sangat baik; dan (10) Kepuasan kegiatan memperoleh rata-rata 3.86 dengan kategori sangat baik.

Saran yang diberikan oleh para guru yang tergabung dalam biodata peserta menyebutkan bahwa pelatihan-pelatihan seperti kegiatan ini diharapkan dapat sering dilakukan karena sangat dibutuhkan terutama yang berhubungan dengan kompetensi guru PAUD. Hasil dari PKM secara garis besar mencakup beberapa komponen sebagai berikut:

1. Keberhasilan Target Jumlah Peserta Pelatihan

Target peserta pelatihan seperti yang direncanakan sebelumnya adalah paling tidak 40 guru di PAUD Formal Binaan I dan III Ciracas Jakarta Timur. Dalam pelaksanaannya, kegiatan ini diikuti oleh 42 orang peserta. Dengan demikian dapat dikatakan bahwa target peserta tercapai 100\%. Angka tersebut menunjukkan bahwa kegiatan PKM dilihat dari jumlah peserta yang mengikuti dapat dikatakan berhasil.

2. Ketercapaian Tujuan Pelatihan

Ketercapaian pendampingan pelatihan pembuatan langkah-langkah mendongeng secara umum sudah baik, namun keterbatasan waktu yang disediakan mengakibatkan kelompok yang mempresentasikan hasil diskusi dan juga memperagakan dongeng di depan hanya sebagian saja. 
3. Ketercapaian Target Materi yang Telah Direncanakan

Ketercapaian target materi pada kegiatan PKM ini sudah cukup baik, karena materi pendampingan telah disampaikan secara keseluruhan. Salah satu materi pendampingan dalam PKM ini adalah Membangun karakter anak dengan media dongeng.

4. Kemampuan Peserta Dalam Penguasaan Materi

Kemampuan peserta dilihat dari penguasaan materi sudah cukup baik, hal tersebut dapat dilihat dari hasil diskusi kelompok dan juga angket yang telah diisi. Namun ada beberapa bapak dan ibu guru yang belum memahami langkah-langkah mendongeng yang baik, sehingga diperlukan bimbingan secara berkelanjutan dalam proses diskusi kelompok.

Secara keseluruhan kegiatan penyuluhan pendidikan karakter melalui media dongeng ini dapat dikatakan berhasil. Keberhasilan ini selain diukur dari keempat komponen di atas, juga dapat dilihat dari kepuasan peserta setelah mengikuti kegiatan. Manfaat yang diperoleh adalah guru menguasai tahapan yang telah diajarkan dalam pelatihan ini, guru dapat membuat langkah-langkah mendongeng yang baik beserta mempraktekkan bercerita di depan kelas sebagai salah satu upaya yang dapat dilakukan seorang guru profesional dalam meningkatan kualitas pembelajaran.

\section{KESIMPULAN}

Hasil yang dicapai dalam pelaksanaan program pengabdian kepada masyarakat berupa "Pelatihan Pembelajaran Karakter Melalui Media Dongeng Pada Paud Formal Binaan I dan Binaan III Ciracas Jakarta Timur" melalui angket yang terkumpul dari 42 responden, diperoleh keterangan bahwa 91,5\% peserta kegiatan menyatakan kegiatan workshop ini tergolong sangat baik. Secara keseluruhan kegiatan penyuluhan pendidikan karakter melalui media dongeng ini dapat dikatakan berhasil.

\section{UCAPAN TERIMA KASIH}

Ucapan terima kasih dapat juga disampaikan kepada pihak-pihak yang membantu pelaksanaan kegiatan.

1. Dekan Fakultas Ilmu Keguruan dan Pendidikan UHAMKA

2. Ketua Jurusan Pendidikan Guru Sekolah Dasar UHAMKA

3. Bapak/Ibu Dosen Jurusan PGSD UHAMKA 
4. Kepala sekolah dan bapak ibu guru Paud Formal Binaan I dan Binaan III Ciracas di wilayah Jakarta Timur

5. Pihak-pihak yang tidak dapat disebutkan satu-persatu dan telah membantu penyusunan proposal PKM

\section{DAFTAR PUSTAKA}

Adhi, M., K. (2014). Model Pendidikan Karakter Berbasis Mendongeng. Jurnal Santiaji Pendidikan. Vol.4(1), 1-12.

Fadlillah, M. (2012). Desain Pembelajaran PAUD. Jogjakarta: AR-RUZZ MEDIA

Fitriyah, Uswatul. (2018). Belajar dengan Media Boneka Tangan.

Sumber:

https://www.kompasiana.com/usfitriyah/5a9bc80916835f424b284725/belajardengan-media-boneka-tangan diunduh 20 Juli 2018

Habsari, Zakia. (2017). Dongeng Sebagai Pembentuk Karakter Anak. BIBLIOTIKA Jurnal Kajian Perpustakaan dan Informasi Vol 1(1), 21-29.

Hasanah, P., S. (2012). Pengaruh Metode BerceritabTerhadap Karakter Anak Usia 5-6 Tahun di TK FKIP UNRI Pekan Baru. (skripsi). FKIP Universitas Riau.

Hurlock, E. (2006). Psikologi Perkembangan. Jakarta: Erlangga

Kartikawati, Eny. (2012). Hanya 33\% Orangtua yang Masih Sempat Mendongeng untuk Anak, (Online), http://wolipop.detik.com/read/2012/10/10/070850/2058848/857/hanya-33-orangtuayang-masih-sempat-mendongeng-untuk-anak. diakses 4 April 2018.

Koswara, Deni. (2008). Seluk-Beluk Profesi Guru. Bandung: Pribumi Mekar

Johnson, Lou Anne. (2009). Pengajaran Yang Kreatif Dan Menarik. Jakarta: Indeks

Pusat Bahasa. (2003). Kamus Pelajar. Jakarta: Departemen Pendidikan Nasional.

Rosdian, Yusi. (2007). Bahasa Dan Sastra Indonesia Di SD. Jakarta: Universitas Terbuka Sari, Evi Dwi Novita dan Fitroh, Siti Fadjryana. (2015). Dongeng Sebagai Media Penanaman Karakter Pada Anak Usia Dini. Jurnal PG-PAUD Trunojoyo, Vol. 2(2), 76-149.

C 2018 Oleh authors. Lisensi Jurnal Solma, LPPM-UHAMKA, Jakarta. Artikel ini bersifat open access yang didistribusikan di bawah syarat dan ketentuan Creative Commons Attribution (CC BY) license (http://creativecommons.org/licenses/by/4.0/). 